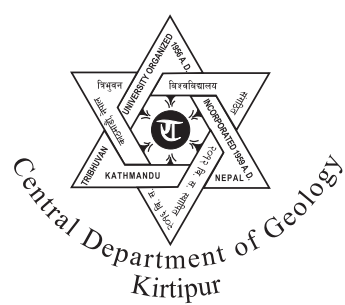

\title{
Petrology and genesis of the Bhainskati iron ore deposit of Palpa District, western Nepal
}

\author{
*Sujan Devkota1 ${ }^{1}$, and Lalu Prasad Paudel ${ }^{2}$ \\ ${ }^{1}$ Department of Mines and Geology, Lainchaur, Kathmandu, Nepal \\ ${ }^{2}$ Central Department of Geology, Tribhuvan University, Kirtipur, Kathmandu, Nepal
}

\begin{abstract}
The Bhainskati Formation of the Tansen Group in the Palpa area is known for hematite iron ore deposit for long time. A prominent band of hematite of about 1-2 $\mathrm{m}$ thickness and extending $>5 \mathrm{~km}$ was identified in the upper part of the Bhainskati Formation in the present study. The band is repeated three times in the area by folding and faulting. Petrographic study shows that it is oolitic ironstone of sedimentary origin. Main minerals in the band are hematite, goethite, quartz, calcite, siderite and albite. Hematite content varies considerably among samples and occurs mainly as oolite and cement. The Bhainskati ironstone with its ferrous mineral assemblage and well-rounded texture of the ooids suggests shallow marine environment (prodeltaic to estuarine) with reduced clastic input.
\end{abstract}

\section{INTRODUCTION}

Hematite, with chemical composition $\mathrm{Fe}_{2} \mathrm{O}_{3}$, is the most abundant and important ore of iron. It is also used in other purposes such as for pigments, red ocher, and as polishing powder. It is widely distributed in rocks of all ages. It may be found in igneous, metamorphic as well as in sedimentary rocks.

In Nepal, iron ores (mainly hematite) have been reported from several parts of the Lesser Himalaya. They are found mainly in the Lower Nawakot Group and in the Tansen Group of the Lesser Himalaya and Phulchoki Group of the Kathmandu Nappe. In the Tansen Group, it is reported in the upper part of the Bhainskati Formation (Sakai, 1983; Hirayama et al., 1988). Hirayama et al. (1988) found that hematite bands occur in three different horizons. However the extension of the hematite and their textural and mineralogical features are still unknown.

*Corresponding author:

E-mail address: lalupaude167@yahoo.com
In the present work, detailed mapping of the hematite bands was carried out in the Bhainskati area of the Palpa District covering an area of about 15 square kilometers. Petrographic features and mineralogical composition of the hematite were studied in both polished and thin sections. Mineralogical composition was also verified by the X-ray diffraction analysis. This paper deals with the results of the studies in detail.

\section{LOCATION AND REGIONAL GEOLOGICAL SETTING}

The Nepal Himalaya occupies the central part (800 $\mathrm{km}$ ) of the $3000 \mathrm{~km}$ long southwardly convex Himalayan arc. The major five morphogenetic zones of the Nepal Himalaya from south to north (Gansser, 1964, Hagen 1969) are the Indo-gangetic plain, Siwaliks, Lesser Himalaya, Higher Himalaya and the Tethys Himalaya.

Present study area lies in the Lesser Himalaya (Fig. 1). The Lesser Himalaya is bordered in the south by the Main Boundary Thrust (MBT) and in the north by 


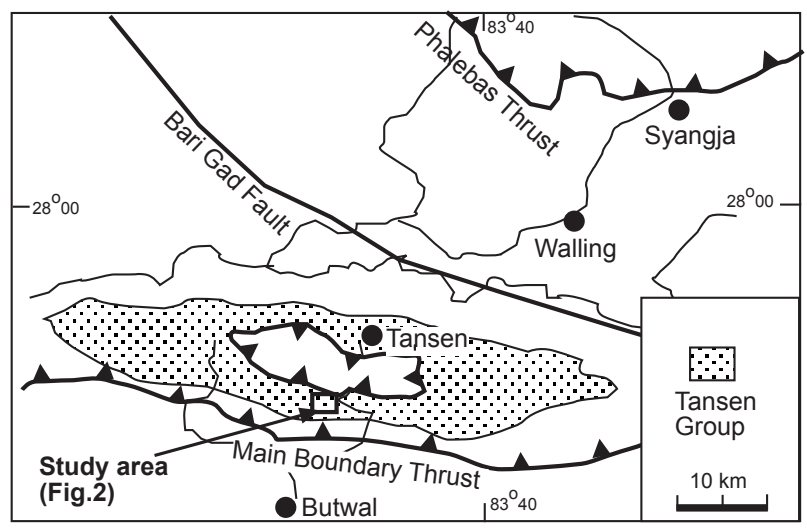

Fig. 1. Geological sketch map of the Tansen-Syangja area showing the location of the study area.

the Main Central Thrust (MCT). The Lesser Himalaya is made up mostly of the unfossiliferous sedimentary and metasedimentry rocks like slate, phyllite, schist, quartzite, limestone and dolomite ranging in the age of the Precambrian to the Oligocene. The Lesser Himalaya in the Tansen area is divided into the Nawakot Complex and the Tansen Group (Sakai, 1983). The Tansen Group comprises rocks from the Permian to the Oligocene and is further divided into the Sisne Formaiton, Taltung Formation, Amile Formation, Bhainskati Formation and the Dumri Formation. Hematite bands have been reported in the Eocene Bhainskati Formation.

\section{FIELD OCCURRENCE OF IRON ORE}

About $5 \times 3$ square kilometer area between Hattiya in the east and Tal in the west was surveyed in the present study. The area is comprised of the Amile, Bhainskati and the Dumri Formations. About 1-2 m thick hematite band occurs at the upper part of the Bhainskati Formation (Figs. 2 and 3). The area forms an east-west trending syncline with the axis passing through Bhainskati. The core of the syncline is occupied by the Dumri Formation. The hematite band is repeated on both the southern and northern limbs of the syncline. The Bhainskati Formation thrusts over the Dumre Formation in the northern part of the study area. Therefore, the hematite band is again repeated in the northern part by the thrust. The southern band of hematite was traced all the way from Hattiya to Besra Bhanjyang and further west to Tal with length of about $5 \mathrm{~km}$. The middle band of the hematite is about $4 \mathrm{~km}$ and can be traced from Jhirbas to Budhi Khatri Kot. The northern band of hematite is about $3 \mathrm{~km}$ long and extends NNW to SSE from Omsran to Jhirbas.

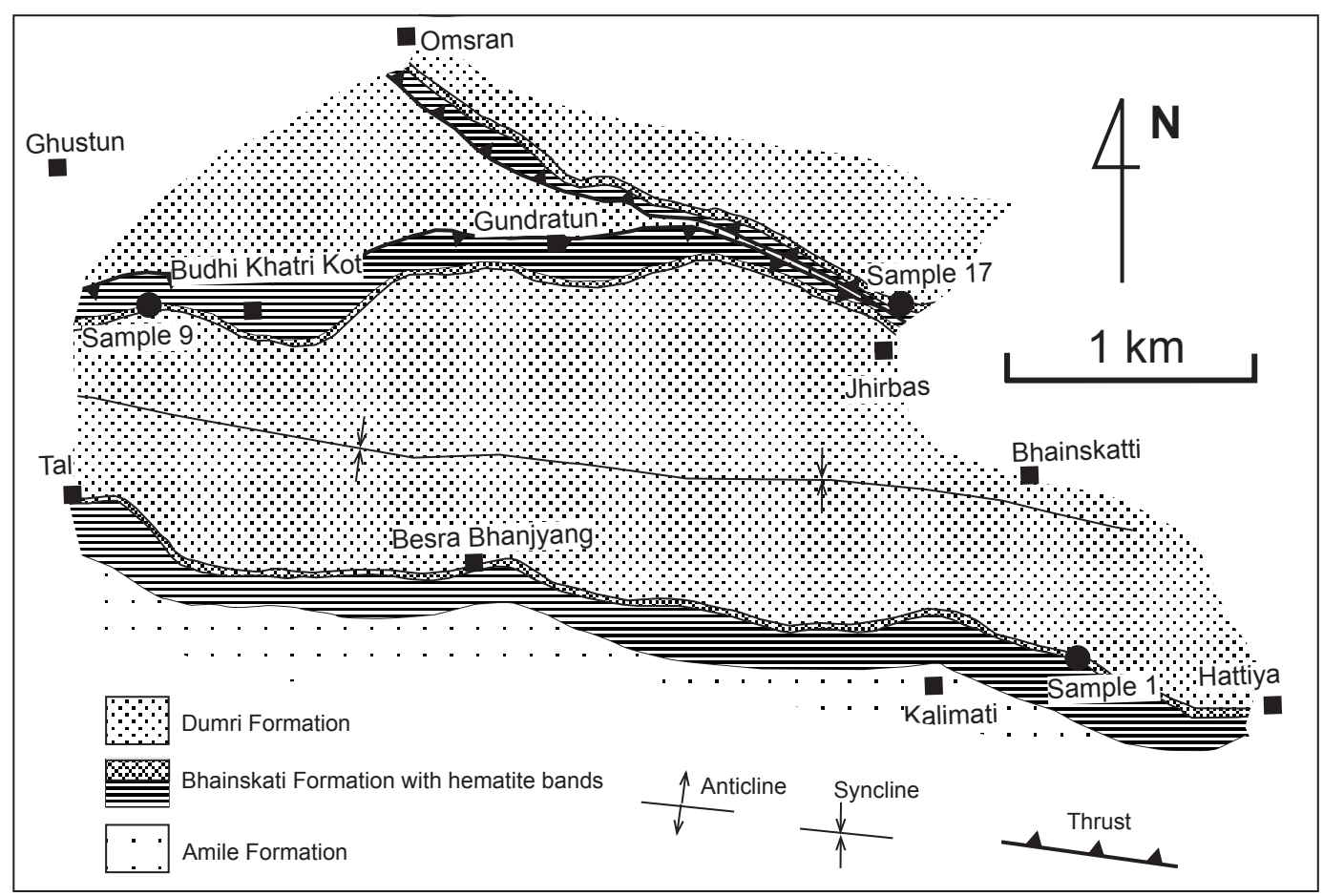

Fig. 2. Geological map of the Bhainskatti area showing the distribution of hematite bands. Hematite band not in scale. 

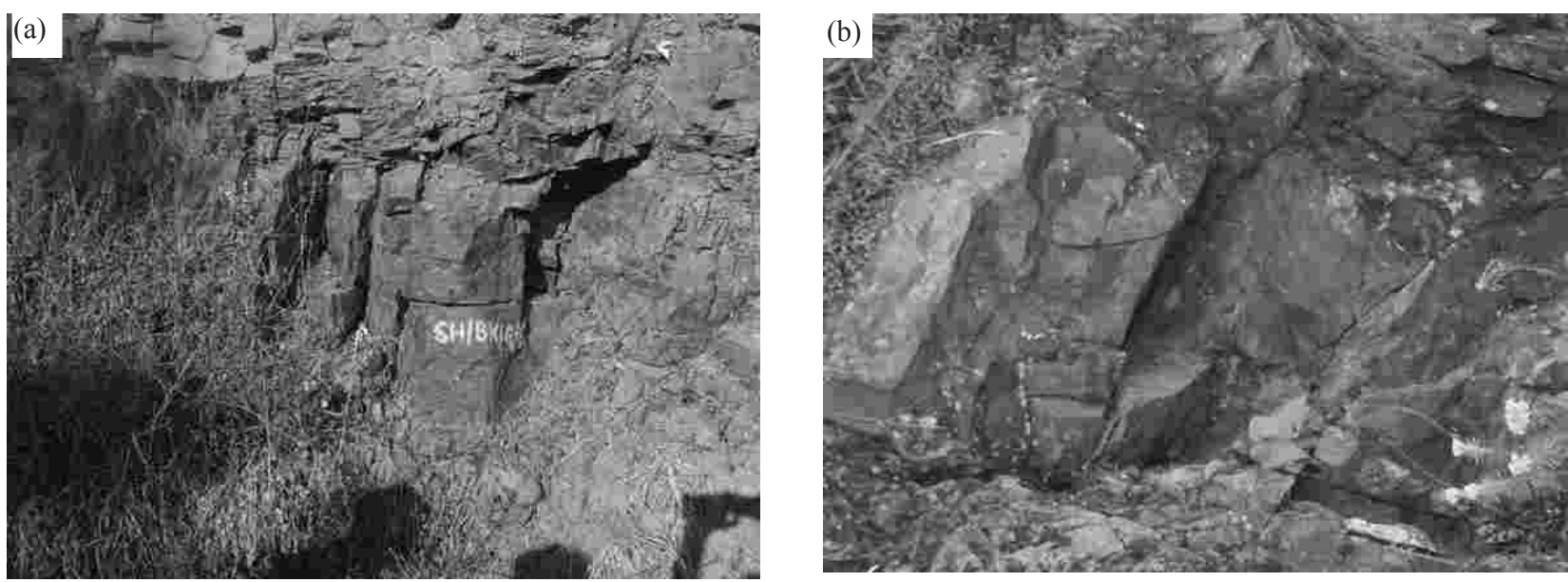

Fig. 3. Photograph showing the outcrop of hematite. (a) Southernmost band. (b) Middle band.

\section{STUDY METHODS}

Topographic maps, published and unpublished reports and literatures, journals, field manuals and established theories related to the present study were collected from the different sources and studied in detail and made the basis for the field investigation. Topographical maps at 1:25,000 scale published by the Survey Department, Government of Nepal was used for the study.

\section{Field Work}

The field work mainly consists of the field mapping which was carried out by the route mapping on 1:25000 scale topographic maps. Geological traverses were made mainly on the roads, rivers and foot trails. The boundaries of the hematite band and host rock formations were marked on the topographic map. Samples were collected as far possible for laboratory analysis.

\section{Thin section study}

Thin-sections (about $0.03 \mathrm{~mm}$ thickness) of each sample were prepared and studied under highmagnification polarized light microscope (transmitted light) with online computer display system. Mineral percentage was determined on area basis. Photomicrographs were taken in representative field under the microscope.

\section{Polished section study}

Polished slabs were prepared of each samples and studied under the ore microscope to identify the opaque minerals.

\section{X-ray Diffractometry}

$\mathrm{X}$-ray Diffraction study was carried out in $<2$ micron powder fraction of the samples. Bruker D8 Advance X-ray diffractometer and DiffracPlus software were used for data acquisition. XRD analysis was done with $\mathrm{CuK} \alpha$ radiation in an angular range $(2 \theta)$ from from $2^{\circ}$ to $40^{\circ}$. Peaks were analyzed an identified using EVA software and Joint Commission for Powder Diffraction System (JCPDS) file database.

Table 1: Summary of perographic and mineralogical data.

\begin{tabular}{|c|c|c|c|c|c|c|c|c|c|c|c|c|}
\hline \multirow[t]{2}{*}{$\begin{array}{c}\text { Sample } \\
\text { No }\end{array}$} & \multicolumn{3}{|c|}{$\begin{array}{c}\text { Clast/matrix/cement } \\
\text { ratio(\%) }\end{array}$} & \multicolumn{2}{|c|}{ Grain size (mm) } & \multicolumn{7}{|c|}{ Mineralogy $(\%)$} \\
\hline & Clast & Matrix & Cement & $\begin{array}{l}\text { Ooids and } \\
\text { other clasts }\end{array}$ & Matrix & Hematite & Geothite & Quartz & Calcite & Siderite & Pyrite & Albite \\
\hline 1 & 45 (ooids) & 10 & 45 & $0.5-1.5$ & $<0.01$ & 85 & 5 & 7 & 1 & NIL & 1 & 1 \\
\hline 9 & $\begin{array}{c}50 \text { (ooids), } 35 \\
\text { (quartz) }\end{array}$ & 10 & 5 & $0.1-1.0$ & $<0.01$ & 35 & 10 & 50 & NIL & NIL & NIL & 5 \\
\hline 17 & 50 (ooids) & 45 & 5 & $0.1-0.6$ & $<0.01$ & 35 & NIL & 55 & 5 & 4 & 1 & NIL \\
\hline
\end{tabular}



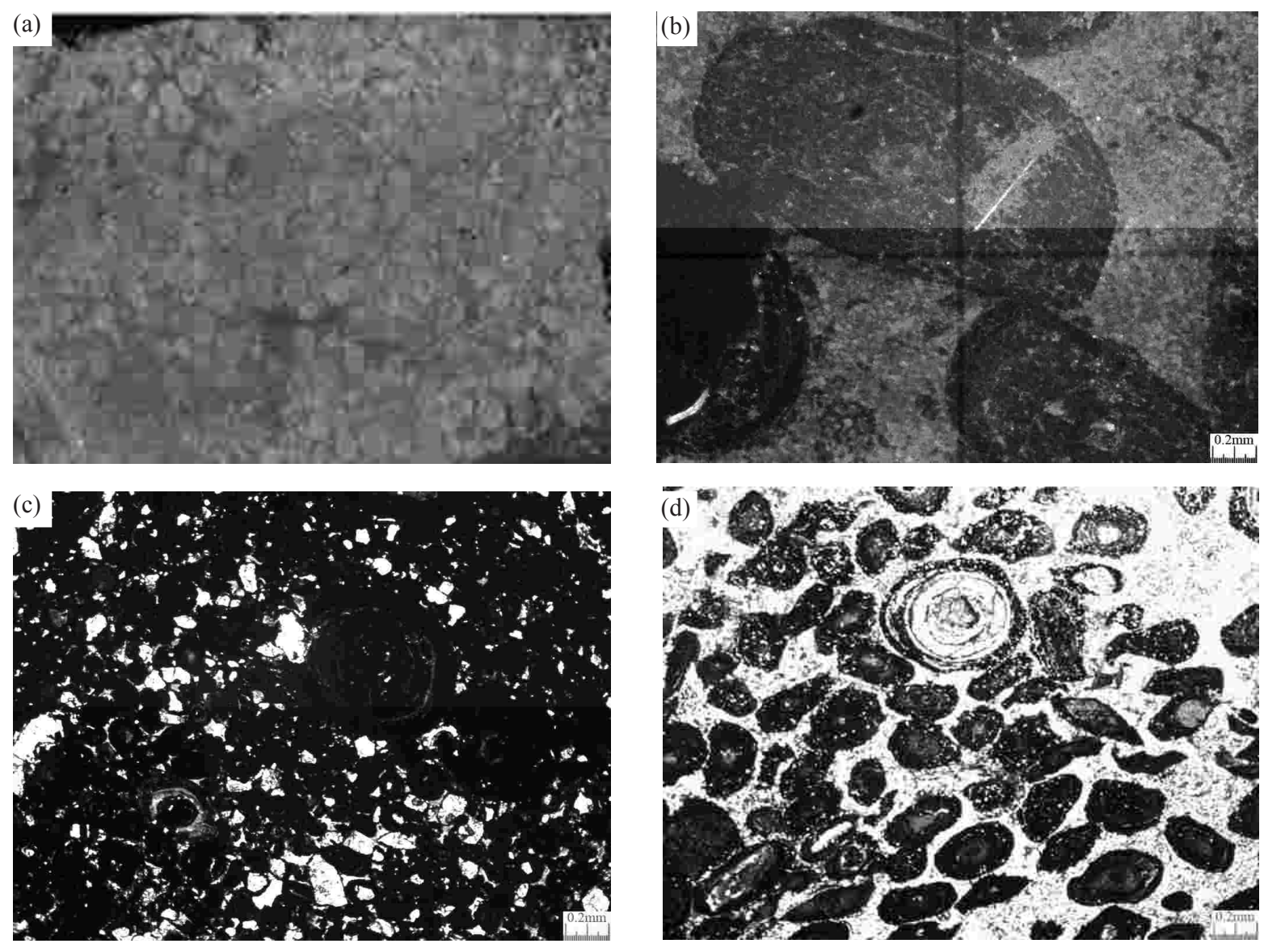

Fig. 4. (a) Polished section of the sample 1. (b) Photomicrograph of sample 1. (c) Photomicrographs of sample 9. (d) Photomicrograph of sample 17.

\section{RESULTS OF PETROGRAPHIC STUDY AND X-RAY DIFFRACTION ANALYSIS}

One representative sample from each band was subjected to the petrological study. The summary of the results of the study are given in the Table 1 .

The study shows that all the samples are oolitic ironstones with variable amount of hematite. Petrographic features of each sample have been described below.

\section{Sample No. 1}

This sample contains the minerals hematite, goethite, quartz, calcite, pyrite and albite (Figs. $4 \mathrm{a}$ and $4 \mathrm{~b}$; Fig. $5)$. The ooids are made up of hematite and goethite. The nuclei of the ooids are dominantly quartz and sometimes pyrite. Calcite is found in micro-veins. The matrix is made up of dominantly angular quartz grains of less than $0.01 \mathrm{~mm}$. The cement is made up of deepred hematite. The ooids are steel grey, spherical, partly elongated and have relatively uniform size, from 0.5 to $1.5 \mathrm{~mm}$. Internally, the ooids are made up of alternating light and dark, thin and nearly continuous concentric layers of hematite and geothite. The number of concentric layers varies from 2 to 6 . The thickness of concentric layers is variable within and among ooids.

\section{Sample No. 9}

This sample comprises the minerals hematite, goethite, quartz, and albite (Figs. $4 \mathrm{c}$ and 6). The sample contains ooids with bimodal grain size. The larger ooids range in size from 0.5 to $1.0 \mathrm{~mm}$ whereas smaller ooids range in size from 0.1 to $0.2 \mathrm{~mm}$ in diameter. The ooids are made up of hematite and geothite. The nuclei of the ooids are of quartz (Fig. 4c). The ooids are spherical. Internally, they are made up of alternating light and dark, thin and nearly continuous concentric layers of 


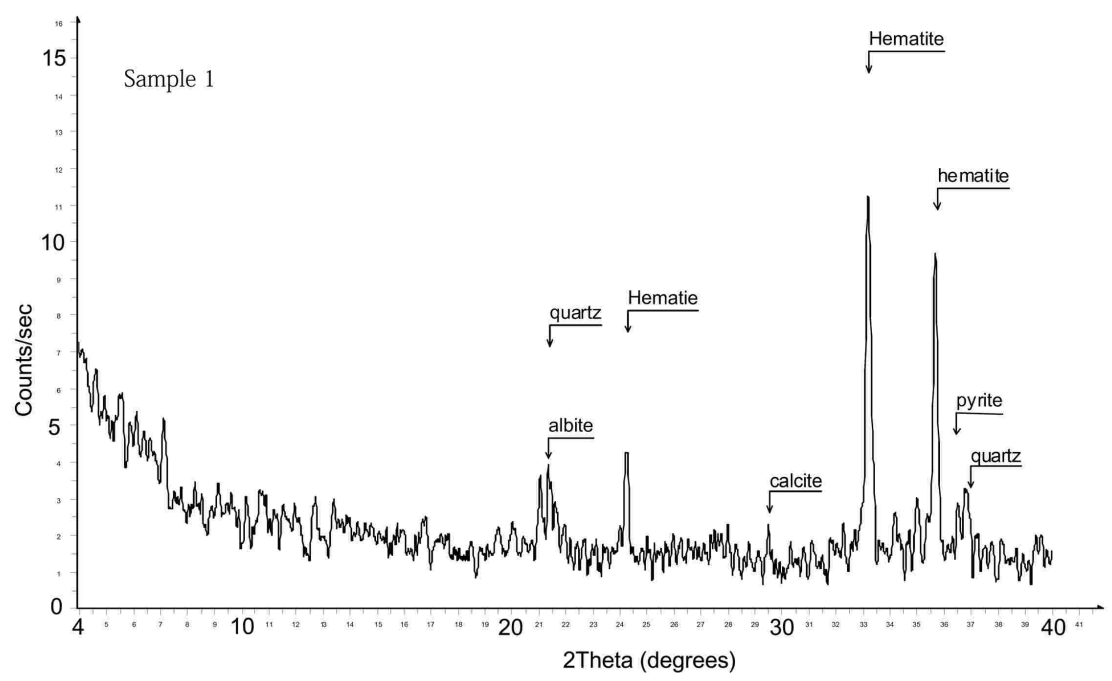

Fig. 5. X-ray Diffractogram of sample 1.

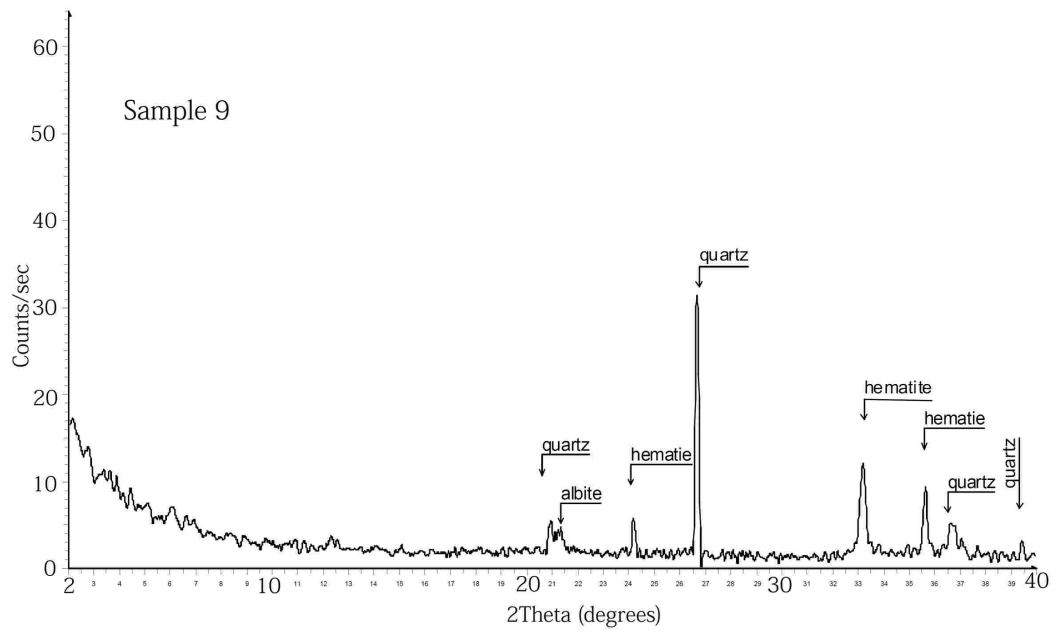

Fig. 6. X-ray Diffractogram of sample 9.

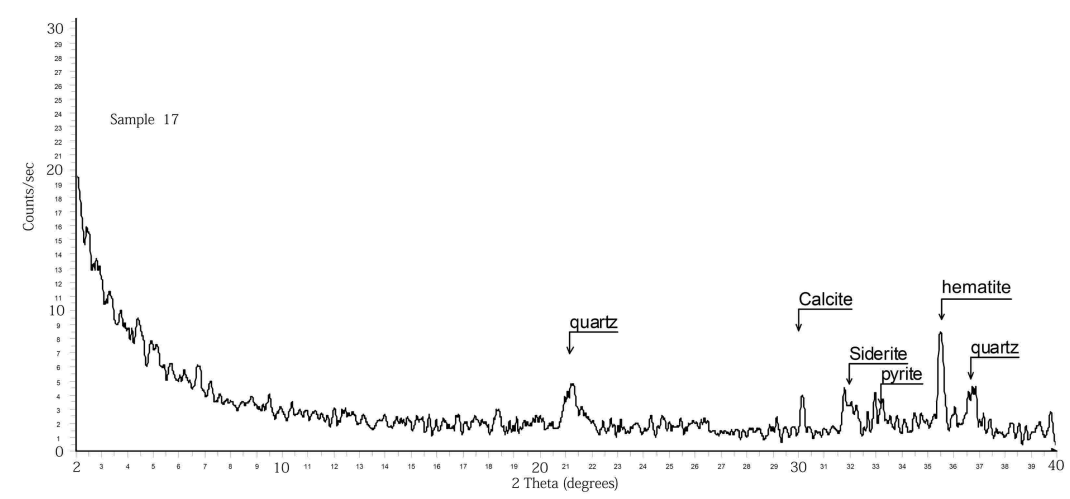

Fig. 7. X-ray Diffractogram of sample 17. 
hematite. The number of concentric layers varies from 2 to 6 . The thickness of concentric layers is variable within and among ooids.

The matrix is dominated by angular grains of quartz smaller than $0.01 \mathrm{~mm}$ size.

\section{Sample No. 17}

This sample is composed of hematite, quartz, calcite, siderite, pyrite and albite (Figs. $4 \mathrm{~d}$ and 7). The sample contains ooids with bimodal grain size. The larger ooids range in size from 0.4 to $0.6 \mathrm{~mm}$ whereas smaller ooids range in size from 0.1 to $0.3 \mathrm{~mm}$ in diameter. The larger ooids are mostly spherical and the smaller ooids are elongated. The nuclei of the ooids are made up of quartz (Fig. 4d). Internally, they are made up of alternating light and dark, thin and nearly continuous concentric layers of hematite and quartz. The number of concentric layers varies from 2 to 6 . The thickness of concentric layers is variable within and among ooids. All the ooids, irrespective of their size, invariably have an outer cortex of quartz. The matrix is dominated by microcrystalline quartz smaller than $0.01 \mathrm{~mm}$ size. Cement is made up of hematite, siderite and calcite.

\section{DISCUSSION ON GENESIS OF THE HEMATITE}

Petrographic features of the Bhainskati hematite show that it is oolitic ironstone. The symmetrical shape, high sorting and absence of broken ooids rule out their transported origin. In addition, preservation of delicate textural features of the ooids would not be likely if they were transported from a distant source. Exquisitely preserved ooid cortices and the absence of relict carbonate phase indicate a non-replacement, primary origin. Therefore, the textures observed in the Bhaisnkati ooidal ironstone indicate authigenic formation of ooids. Some researchers believe that the concentric fabric of ooids is a primary structure produced by mechanical accretion of clay particles. Several recent studies of other ooidal ironstone deposits elsewhere in the world, have proposed that ooidal ironstone was a result of specific sedimentary processes like low sedimentation rate (Van Houten et al., 1984). The Bhainskati ironstone with its ferrous mineral assemblage and well-rounded texture of the ooids suggests shallow marine environment (prodeltaic to estuarine) with reduced clastic input. The unique characteristics of the ooidal ironstones may represent excellent marker horizons for stratigraphic correlation among Gondwana-type sediments in the Lesser Himalaya.

\section{CONCLUSIONS}

Hematite band with thickness about 1-2 m occurs in the upper part of Bhainskati Formation of the Tansen Group. It is exposed as a continuous band for more than $5 \mathrm{~km}$ WNW-ESE direction and is repeated at three places in the area by folding and faulting. Petrographic study and X-ray diffraction analysis carried out in the samples show that it is oolitic ironstone of sedimentary origin. Main minerals in the samples are hematite, goethite, quartz, calcite, siderite and albite. Hematite content is varies considerably among samples and occurs mainly as oolite and cement. The Bhainskati ironstone with its ferrous mineral assemblage and well-rounded texture of the ooids suggests shallow marine environment (prodeltaic to estuarine) with reduced clastic input.

\section{ACKNOWLEDGEMENTS}

We are thankful to the Central Department of Geology, TU for providing its laboratory facilities for the analysis of samples.

\section{REFERENCES}

Gansser, A., 1964. Geology of the Himalayas. Wiley Interscience, New York pages 289.

Hagen, T., 1969. Reports on the geological survey of Nepal, Preliminary Reconnaissance. Denkscher. Schweiz. Naturf. Ges. 86: 185 pages.

Hirayama, J., Nakajima, T., Shrestha, S.B., Adhikari, T.P., Tuladhar, R.M., Tamrakar, J.M., Chitrakar, G.R., 1988. Geology of southern part of the Lesser Himalaya, west Nepal. Bulletin of the Geological Survey of Japan 39, 205-249.

Sakai, H., 1983. Geology of the Tansen Group of the Lesser Himalaya in Nepal. Memoirs of the Faculty of Science, Kyushu University, Series D 25:27-74.

Van Houten, F. B. and Purucker, M. E., 1984.Glauconitic peloids and chamositic ooids - Favorable factors, constraints, and problems. Earth Science Review 20: 211-243. http://dx.doi.org/10.1016/00128252(84)90002-3 